\title{
Alternative Sustainable Binder for Concrete Construction: Wood Ash as a Cement Replacement
}

\author{
Sevket Can Bostanci ${ }^{1 *}$ \\ ${ }^{1 *}$ European University of Lefke, Faculty of Engineering, Department of Civil Engineering, Lefke, Northern Cyprus, TR-10, Mersin, Turkey (ORCID: 0000-0002- \\ 1493-6147), sbostanci@eul.edu.tr
}

(First received 29 October 2021 and in final form 16 December 2021)

(DOI: 10.31590/ejosat.1016330)

ATIF/REFERENCE: Bostanci, S.C. (2021). Alternative Sustainable Binder for Concrete Construction: Wood Ash as a Cement Replacement. European Journal of Science and Technology, (31), 594-608.

\begin{abstract}
The use of waste materials in concrete production has been highly encouraged recently to minimize the environmental problems. Portland cement is a high energy-intensive constituent material that contributes to $\mathrm{CO}_{2}$ emissions. Local waste materials are trending in concrete production due to shorter transportation distances that do not contribute to $\mathrm{eCO}_{2}$ emissions. Wood ash is one of the available wastes in Cyprus which is potentially disposed of through landfill. This study aimed to several various engineering properties (slump, bulk density, compressive strength, water permeability) performances of concrete mixes made with 95\% Portland cement (PC) and 5\% wood ash (WA) for $28 \mathrm{~d}$ target design strengths of $30 \mathrm{MPa}$ and $45 \mathrm{MPa}$. In addition, further assessment was established to investigate the potential sustainability performance of the laboratory mixes from environmental ( $\mathrm{eCO}_{2}$ emissions), economic and social (thermal conductivity and sound permeability) point of view. Studies of engineering properties, comprising slump, compressive strength and water permeability, showed either similar or slightly improved performances for WA mixes compared to PC mixes, while WA addition increased bulk density. Concerning sustainability performance, WA use decreased $\mathrm{eCO}_{2}$ emissions compared to conventional mixes. Social sustainability indicators had also enhanced performances for WA mixes indicating an encouraging approach for lower impact concrete production.
\end{abstract}

Keywords: Sustainable Construction, Sustainable Concrete, Wood Ash, Thermal Conductivity, Sound Permeability, Engineering.

\section{Beton Üretiminde Alternatif Sürdürülebilir Bağlayıcı: Çimento Yerine Odun Külü Kullanımı}

\section{$\ddot{O} z$}

Çevre sorunlarının en aza indirilmesi için atık malzemelerin beton üretiminde kullanılması son zamanlarda oldukça teşvik edilmektedir. Portland çimentosu (PC), $\mathrm{CO}_{2}$ emisyonlarına katkıda bulunan, yüksek enerji yoğun bileşenli bir malzemedir. Yerel atık malzemeler, eCO 2 emisyonlarına katkıda bulunmayan daha kısa nakliye mesafeleri nedeniyle beton üretiminde tercih ediliyor. Odun külü (WA), Kıbrıs'ta potansiyel olarak çöplük yoluyla bertaraf edilebilecek mevcut atıklardan biridir. Bu çalışma, $30 \mathrm{MPa}$ ve $45 \mathrm{MPa}$ 'lık 28 gün (28 d) hedef tasarım dayanımları için \%95 Portland çimentosu ve \%5 odun külü ile yapılan beton karışımlarının çeşitli mühendislik özelliklerini (çökme, kütle yoğunluğu, basınç dayanımı, su geçirgenliği) performanslarını değerlendirmeyi amaçlamıştır. Ek olarak, laboratuvar karışımlarının çevresel (eCO $\mathrm{CO}_{2}$ emisyonları), ekonomik ve sosyal (termal iletkenlik ve ses geçirgenliği) açısından potansiyel sürdürülebilirlik performansını araştırmak için daha fazla değerlendirme yapılmıştır. Çökme, basınç dayanımı ve su geçirgenliğini içeren mühendislik özellikleri çalışmaları, WA karışımları için PC karışımlarına kıyasla benzer veya biraz daha iyi performans gösterirken, WA ilavesi kütle yoğunluğunu arttırdı. Sürdürülebilirlik performansı ile ilgili olarak, WA kullanımı, geleneksel karışımlara kıyasla $\mathrm{eCO}_{2}$ emisyonlarını azalttı. Sosyal sürdürülebilirlik göstergeleri, sürdürülebilir beton üretimi için umut verici bir yaklaşıma işaret eden WA karışımları için performansları da artırdı.

Anahtar Kelimeler: Sürdürülebilir İnşaat, Sürdürülebilir Beton, Odun Külü, Termal İletkenlik, Ses Geçirgenliği, Mühendislik.

\footnotetext{
* Corresponding Author: sbostanci@eul.edu.tr
} 


\section{Introduction}

The concrete industry undertakes $8 \%$ of the global $\mathrm{CO}_{2}$ emissions. Environmental destruction of concrete production through releasing $\mathrm{CO}_{2}$ emissions to the atmosphere is usually associated with Portland cement (PC) use. Considerable amount of embodied $\mathrm{CO}_{2}\left(\mathrm{eCO}_{2}\right)$ emissions and embodied energy are required during the production of PC (Timperley, 2018; Sanal, 2018). Countries agree to cut down their $\mathrm{CO}_{2}$ emissions which contribute to global warming under the Kyoto Protocol in 1990 (Climate Change Secretariat, 2008). Similar concerns were stressed again in the Paris agreement in 2015 (United Nations, 2015).

Attention was paid primarily to the utilization of environmentally-efficient and locally available waste materials in concrete manufacturing to minimize emissions through production and transportation. Waste materials have been introduced in the last couple of decades as alternative cementitious materials to replace PC. Several studies were conducted to determine the applicability of these materials based on mechanical and environmental performances (Bostanci, Limbachiya, \& Kew, 2018; Scrivener, John, \& Gartner, 2018; Aydin \& Arel, 2019; Meddah, 2017; Onuaguluchi \& Eren, 2016; Sanal, 2018; Ruan \& Unluer, 2017; Ince, 2019). Local wastes depend on the traditional habits and availability. The use of these materials, depending upon their effectiveness, could potentially minimize emissions and lower the cost of transportation and production. Wood ash (WA) waste through wood burning for domestic heating purposes is usually available in developing countries. When obtained, it could be used as a filler material in concrete production (da Luz Garcia, 2013) or as fertilizing application of soil (Prabagar, Subasinghe, \& Fonseka, 2015). There is no standard disposal method for WA. As a consequence, it could lead to health problems through air-borne of fine materials in windy conditions and contamination of the groundwater from leaching of heavy metal contents through landfilling (Udoeyo, Inyang, Young, \& Oparadu, 2006). As WA is not globally available material, a very few studies on WA incorporated concretes have been performed. According to Siddique (Siddique, 2012), the use of WA is limited due to higher carbon content and its properties vary depending upon the type of wood and burning temperature. These varying inherent and chemical properties result in contradicting results. Naik (Naik, Kraus, \& Siddique, 2003) stated that the source has a remarkable influence on the physical and chemical properties of ash additive concretes. A study by Chowdury (Chowdury, Mishra, \& Suganya, 2015) noted the lower workability of WA incorporated mixes. A similar finding was reported by Cheah (Cheah \& Ramli, 2012) with WA content varying from $5 \%$ up to $25 \%$ reduced workability. Udoeyo (Udoeyo, Inyang, Young, \& Oparadu, 2006) found significant slump loss of up to $15 \%$ WA content whereas no slump was available at further replacement levels. In addition, Abdullahi (Abdullahi, 2006) modified the $\mathrm{w} / \mathrm{b}$ ratios and reported improved slump values for mixes with WA content up of to $40 \%$. Luz Garcia (da Luz Garcia, 2013) also observed a slight improvement in fresh properties with 5\% and 10\% WA content. Similar workability was also recorded by Pavlikova (Pavlikova, et al., 2018) for $10 \%$ replacement levels, whereas workability was decreased for greater than $10 \%$ replacement level. When considering hardened properties, bulk density is more apparent as WA content increments due to the lower specific gravity of WA (Chowdury, Mishra, \& Suganya, 2015), (Cheah \& Ramli, 2011; Kizinevic \&
Kizinevic, 2016). No specific trend has been observed for bulk density by Cheah (Cheah \& Ramli, 2011) and Pavlikova (Pavlikova, et al., 2018) when WA is introduced. Earlier studies reported reduction in compressive strength for WA concrete mixes (da Luz Garcia, 2013; Cheah \& Ramli, 2011; Kizinevic \& Kizinevic, 2016). Some studies (da Luz Garcia, 2013; Cheah \& Ramli, 2011) stated that this reduction was attributed to the filling effect of WA. On the contrary, few studies (Prabagar, Subasinghe, \& Fonseka, 2015; Chowdury, Mishra, \& Suganya, 2015) reported that $15 \%$ of WA use improved the compressive strength due to the pozzolanic property of WA. In addition, there was no negative effect on the compressive strength reported up to $8 \%$ of WA content (Naik, Kraus, \& Siddique, 2002). Udoeyo (Udoeyo, Inyang, Young, \& Oparadu, 2006) and Cheah (Cheah \& Ramli, 2012) found that 5\% WA replacement level is acceptable in terms of the compressive strength. However, Ramos (Ramos, Matos, \& Sousa-Coutinho, 2013) and Pavlikova (Pavlikova, et al., 2018) reported improved compressive strength for mixes with $10 \%$ WA content. As far as the durability properties concerned, previous studies reported gradual improvement as WA content increased (Cheah \& Ramli, 2012; Cheah \& Ramli, 2011; Kizinevic \& Kizinevic, 2016; Udoeyo, Inyang, Young, \& Oparadu, 2006). In contrast, Prabagar (Prabagar, Subasinghe, \& Fonseka, 2015) observed reduction in water absorption values for WA mixes composed of $10 \%, 15 \%$ and $20 \%$ WA contents. This contradicting trend was also observed for the porosity property. Previous studies (Kizinevic \& Kizinevic, 2016; Rissanen, et al., 2019) reported an increase in porosity when using WA whilst Pavlikova (Pavlikova, et al., 2018) found a reduction in porosity for mixes with $10 \%$ and $15 \%$ WA contents. From the mechanical point of view, Ekinci (Ekinci, Hanafi, \& Aydin, 2020) stated that 5\% WA content is the optimum replacement level for WA to improve concrete matrix.

In general, established literature suggested contradicting performances on the engineering properties of WA concretes. These mixes were produced with 5\% WA content as a replacement of $\mathrm{PC}$ and aimed to have $28 \mathrm{~d}$ target design strengths of $30 \mathrm{MPa}$ and $45 \mathrm{MPa}$. When sustainability performance is concerned, there is no clear available analytical data carried out on the sustainability performance (environmental, economic and social) of WA incorporated concretes. Against this background, this study targeted to investigate the basic engineering properties including slump value, bulk density, compressive strength, and water permeability of laboratory mixes. Sustainability performances of laboratory mixes were, then, carried out based on environmental, economic and social perspectives. Environmental sustainability includes $\mathrm{eCO}_{2}$ emissions analysis while economic sustainability considers costs of developed mixes. Social sustainability focusses on the health and well-being relevant measures including thermal conductivity and sound permeability.

\section{Material and Method}

\subsection{Materials}

\subsubsection{Cement}

CEM I was used in accordance with TS EN 197-1 (Turkish Standards Institution, TS EN 197-1, 2012). PC had Blaine fineness of $305 \mathrm{~m}^{2} / \mathrm{kg}$ and specific gravity reported from the supplier was 3.15. The chemical compositionof the PC, based on atomic mass, is provided in Table 1. 


\subsubsection{Wood Ash}

A was used to replace $\mathrm{PC}$ by $5 \%$ on a mass basis $(95 \% \mathrm{PC}+5 \% \mathrm{WA})$ to promote environmentally efficient concrete production. WA was collected from the author's own house from the fireplace burning for heating purposes. The average burning temperature is believed to be around $500^{\circ}-600^{\circ}$. Most of WA collected was from the olive tree. Trees were cut down by the local government due to highway construction and then cut into pieces with the permission of the forestry department. It is worth to mention that the wood used for heating was responsibly sourced in a sustainable manner. The sieve size used was $425 \mu \mathrm{m}$ to ensure uniformity in shape. This sieve size was used to maximize the amount of material obtained. Fig. 1 gives the grading of the both
PC and WA. The chemical composition, based on atomic mass, of WA is revealed in Table 1. WA specific gravity was 1.7 .

\subsubsection{Aggregates}

Natural sand and gravel were used in this study. Sand, with nominal size of $5.6 \mathrm{~mm}$, and gravel, with nominal size of $22.4 \mathrm{~mm}$, were used in conformity with TS 706 EN 12620+A1 (Turkish Standards Institution, TS 706 EN 12620+A1, 2009). Relevant aggregates characteristics are presented in Fig. 2 and Table 2.

\subsubsection{Admixtures}

Water reducing agent, BASF MasterGlenium 126, was used as chemical admixture conforming to TS EN 934-2.

\section{Table 1. Chemical Compositions of Cementitious Materials}

\begin{tabular}{l|c|c}
\hline Compound & $\begin{array}{c}\text { PC } \\
(\mathbf{\%})\end{array}$ & $\begin{array}{c}\text { WA } \\
\text { (\%) }\end{array}$ \\
\hline $\mathrm{SiO}_{2}$ & 21.2 & 18.1 \\
\hline $\mathrm{CaO}$ & 64.7 & 44.4 \\
\hline $\mathrm{Al}_{2} \mathrm{O}_{3}$ & 5.1 & 3.3 \\
\hline $\mathrm{Fe}_{2} \mathrm{O}_{3}$ & 2.5 & 2.8 \\
\hline $\mathrm{MgO}$ & 0.9 & 2.8 \\
\hline $\mathrm{SO}_{3}$ & 1.5 & 0.9 \\
\hline $\mathrm{K}_{2} \mathrm{O}$ & 0.2 & 5.2 \\
\hline Loss on ignition & 2.5 & 22.1 \\
\hline
\end{tabular}

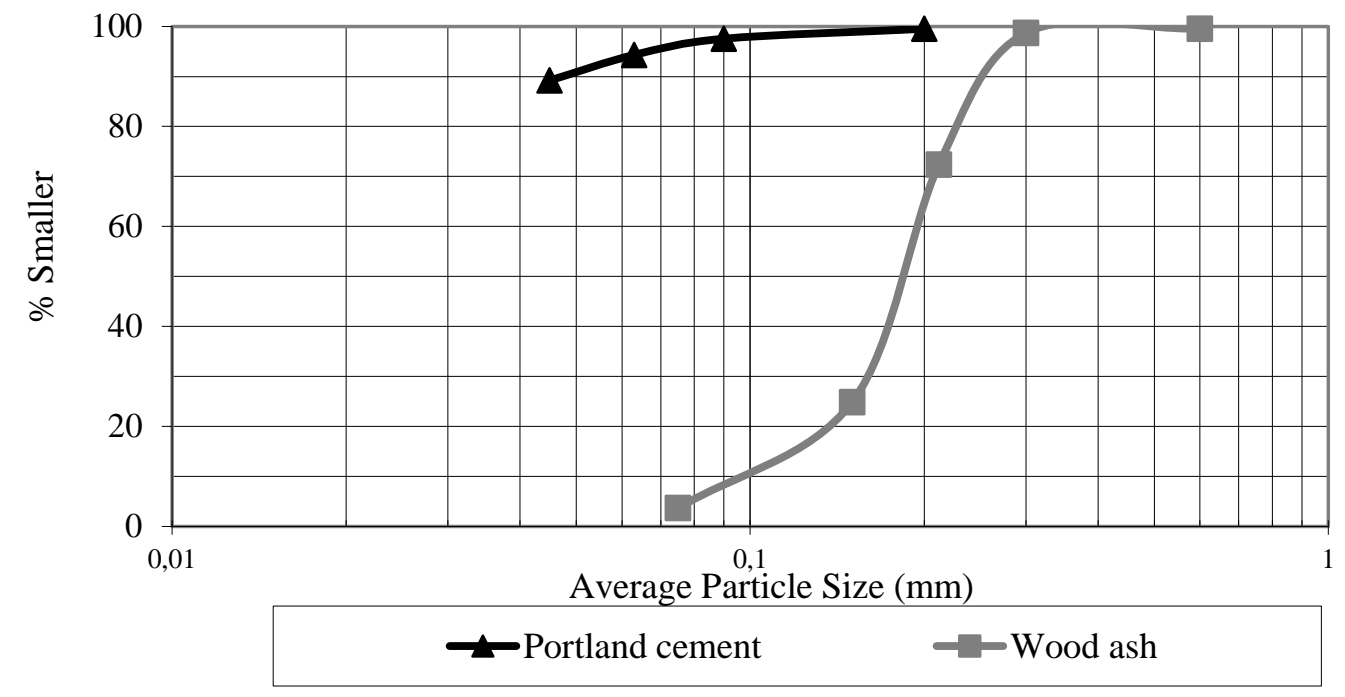

Figure 1. Particle Size Distribution of Portland Cement and Wood Ash 


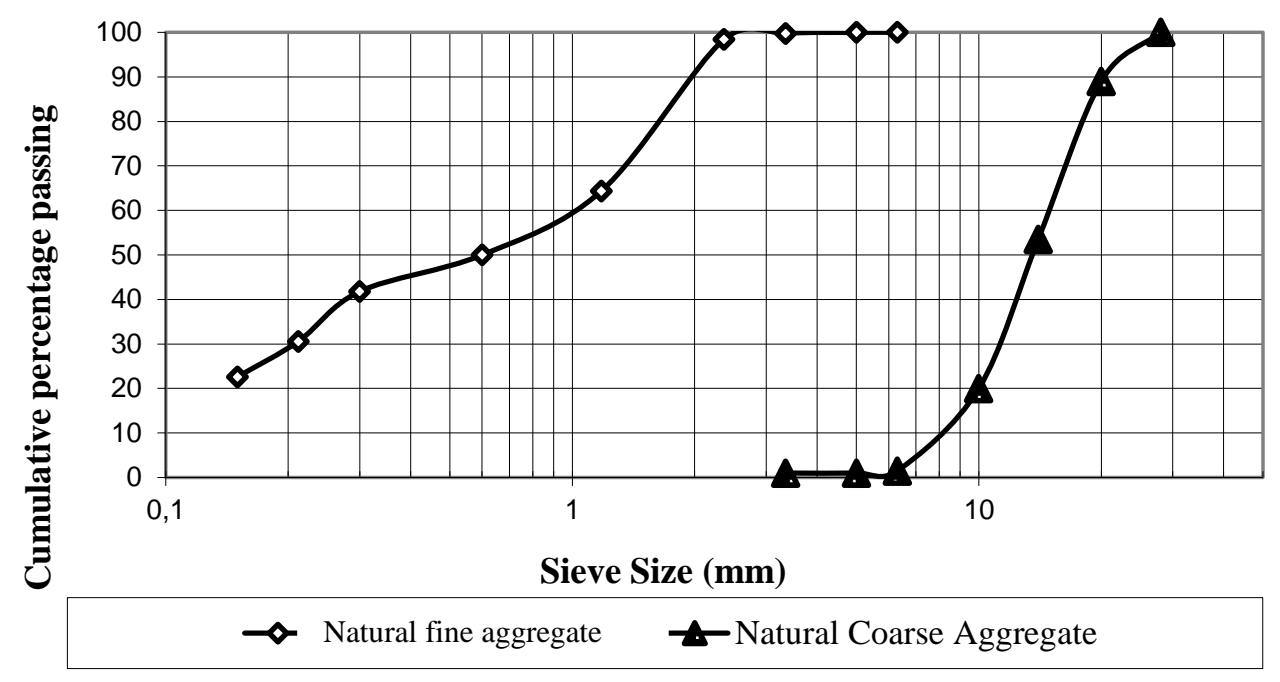

Figure 2. Grading of Fine and Coarse Aggregates

Table 2. Aggregates Physical and Mechanical Properties

\begin{tabular}{l|c|c}
\hline Property & \multicolumn{2}{|c}{ Aggregates } \\
\hline Physical $($ TS EN 1097, part 6) & 1.64 & Coarse \\
\hline Unit weight $\left(\mathrm{kg} / \mathrm{m}^{3}\right)$ & 42.2 & 1.50 \\
\hline Percentage of voids (\%) & 2.85 & 42.1 \\
\hline Apparent density $\left(\mathrm{kg} / \mathrm{m}^{3}\right)$ & 0.84 & 2.61 \\
\hline Water absorption capacity (\%) & 2.84 & 1.40 \\
\hline Specific gravity & 2.92 & 2.59 \\
\hline Fineness modulus & & 4.34 \\
\hline
\end{tabular}

Table 3. Mix Proportions of Laboratory Mixes

\begin{tabular}{|c|c|c|c|c|c|c|c|c|}
\hline \multirow{3}{*}{$\begin{array}{l}\text { Target Design } \\
\text { strength } \\
\text { (MPa) }\end{array}$} & \multirow{3}{*}{ Mixes } & \multicolumn{6}{|c|}{ Mix Proportions $\left(\mathrm{kg} / \mathrm{m}^{3}\right)$} & \multirow{3}{*}{$\begin{array}{c}\mathbf{w} / \mathbf{b} \\
\text { ratio }\end{array}$} \\
\hline & & \multirow{2}{*}{ Water } & \multicolumn{2}{|c|}{ Cementitious Materials } & \multicolumn{2}{|c|}{ Aggregates } & \multirow{2}{*}{ Superplasticizer } & \\
\hline & & & PC & WA & Fine & Coarse & & \\
\hline \multirow{2}{*}{30} & $\mathrm{PC}$ & 220 & 380 & - & 685 & 1040 & 3.80 & \multirow{2}{*}{0.58} \\
\hline & WA & 220 & 360 & 20 & 685 & 1040 & 3.60 & \\
\hline \multirow{2}{*}{45} & $\mathrm{PC}$ & 220 & 490 & - & 825 & 790 & 4.90 & \multirow{2}{*}{0.45} \\
\hline & WA & 220 & 465 & 25 & 825 & 790 & 4.65 & \\
\hline
\end{tabular}

Table 4. Test Ages for the Performed Tests

\begin{tabular}{l|c|c}
\hline \multirow{2}{*}{ Property } & $\begin{array}{c}\text { PC } \\
(\mathbf{\%})\end{array}$ & $\begin{array}{c}\text { WA } \\
(\%)\end{array}$ \\
\hline Engineering & Compressive strength, MPa & $1,7,14,28$ and 56 \\
\cline { 2 - 3 } & Water Permeability, $(\%)$ & 28 and 56 \\
\hline Sustainability & Thermal Conductivity, $(\lambda(\mathrm{W} / \mathrm{mK}))$ & 28 and 56 \\
\cline { 2 - 3 } & Sound Permeability, $(\%)$ & 28 and 56 \\
\hline
\end{tabular}

\subsection{Mix Proportioning and Design}

Mix proportions were established according to the Building Research Establishment document. Two different concrete grades, $30 \mathrm{MPa}$ and $45 \mathrm{MPa}$, were considered in this study to address medium and high strength concrete applications respectively. The water/binder $(\mathrm{w} / \mathrm{b})$ ratios were 0.58 and 0.45 for $30 \mathrm{MPa}$ and 45 $\mathrm{MPa} 28 \mathrm{~d}$ target design strength mixes. Concrete densities were established considering the density of the coarse aggregate. Concrete density was determined as $2325 \mathrm{~kg} / \mathrm{m}^{3}$ for both control and WA mixes. The consistency class of S3 were sought, 100-150 $\mathrm{mm}$, according to TS EN 206:2013+A1. Control mixes were 
sought to achieve $28 \mathrm{~d}$ target cube strengths of $30 \mathrm{MPa}$ and 45 $\mathrm{MPa}$. Four mixes were produced for this study, two PC only control mixes and in the other two mixes $\mathrm{PC}$ was replaced by $5 \%$ WA on mass basis. WA content was kept at 5\% of total cementitious content due to the limited availability of WA waste. Superplasticizer contents were kept as $1 \%$ of the PC content for all mixes. Mixes were denoted initially based on their target design strength and then cementitious type used. Control mixes were denoted as 30-PC and 45-PC whilst WA mixes were denoted as 30-WA and 45-WA. Mix proportions are presented in Table 3.

\subsection{Test Methods}

Laboratory mixes were cast complying with TS EN 12350 and samples were then covered for post 24 hours. Samples were demoulded after 24 hours and water cured at $20^{\circ} \mathrm{C}$ until testing according to the requirements of TS EN 12390-2. Tests conducted and relevant test ages. are presented in Table 4. Three samples were used for each test and results were established.

\subsection{Sustainability Analyses}

\subsubsection{Environmental Sustainability}

Current concrete applications are associated mostly with its environmental performance ( $\mathrm{eCO}_{2}$ emission analysis) to keep up with sustainable development principles defined in the Brundtland report (Brundtland, 1987). As PC is the main contributor to $\mathrm{eCO}_{2}$ emissions, replacing energy-intensive $\mathrm{PC}$ with waste materials or by-products will undoubtedly lower the $\mathrm{eCO}_{2}$ emissions (Yilmaz, Tokyay, \& Yaman, 2016; Shi, Qu, \& Provis, 2019). The overall assessment of sustainability principles included environmental, economic and social impact. Huising (Huising, Zhang, Moore, Qiao, \& Li, 2015) suggested that carbon reduction strategies to satisfy sustainable development should start from the smallest scale, as possible, which will then affect the global scale. Current practices do not fully favour replacing PC with environmentally-efficient waste materials due to their poor mechanical performance, associated mostly with compressive cube strength. Then, the relationship between $\mathrm{eCO}_{2}$ emissions with $28 \mathrm{~d}$ compressive strength was determined. Sustainability analyses were performed by considering materials delivery to the casting site. PC was imported from abroad, and thus, emissions regarding to $\mathrm{PC}$ production and use consider raw materials processing, delivery to the seaport, sea transport from Turkey to North Cyprus, delivery from the seaport to silo, carrying to silo for storage and emptying from the silo to production site. Extraction and processing of aggregates were accounted and followed by delivering to the concrete casting. The data regarding $\mathrm{eCO}_{2}$ emissions of these materials were obtained in cooperation with the Kascon Ready-mixed concrete company limited and its sub-company Üstaş limited where the natural aggregates were obtained. Only $\mathrm{eCO}_{2}$ emissions based on transportation from the place of collection to casting sites were included in the calculations of WA material. Table 5 summarized the equivalent $\mathrm{eCO}_{2}$ emissions (Hammond \& Jones, 2011; International Maritime Organization, 2014; Rossit \& Lawson, 2012) of the constituents while Table 6 lists the costs of materials.

\subsubsection{Economic Sustainability}

Economic efficiency is one of the pillars of the sustainability (Jeon, Amekudzi, \& Guensler, 2013; Zito \& Salvo, 2011) Shiau and Liu (Shiau \& Liu, 2013) stated that economic evaluation is one of the tools to assess sustainability. Another study expressed that sustainable transportation could provide a bridge between environmental and economic sustainability (Abbasi \& Nilsson, 2016). Santos (Santos, Limbourg, \& Carreira, 2015) pointed out that economic sustainability is prioritized compared to environmental and social sustainability. A report by Federal Highway Administration considers material phase including raw materials extraction and manufacturing, transportation to the plant, mix design and proportioning and from the plant to the construction site (Federal Highway Administration, 2016). It is also stated that emissions are based on the type of the transport. Considering these, costs of materials through transportation and production are given in Table 6 . All distances are taken into account considering their delivery to the construction site, European University of Lefke. Cost of each material per tonne are calculated based on national tariffs for both production and transportation stages.

\subsubsection{Social Sustainability}

People require comfortable open areas in order to enhance the quality of living (Barbulescu \& Lafargue, 2016; Akadiri, Chinyio, \& Olomolaiye, 2012). Plati (Plati, 2019) revealed that social sustainability is of great importance which could expose negative impact on people if it is ruined. Hajek (Hajek, 2017) stated concrete could contribute to social sustainability through its inherent thermal mass and acoustic characteristics.

\subsubsection{Thermal Conductivity}

As the quality of the life for the occupants has been one of the major focus points under the sustainable construction tools (Mishra, 2020), construction materials with better inherent thermal conductivity property has drawn interest. Building fabric having lower thermal conductivity could also lower the energy demand for heating and cooling (Leo Samuel, Dharmasastha, Shiva Nagendra, \& Prakash Maiya, 2017). The existing literature has examined thermal conductivity through various methods (Asadi, Shafigh, \& Mahyuddin, 2018; Kazmi, Munir, Wu, Hanif, \& Patnaikuni, 2018; Pedreño-Rojas, Morales-Conde, PérezGálvez, \& Rodríguez-Liñán, 2017). The thermal conductivity test was carried out through steady state principle guarded hot plate test apparatus in this study. Concrete samples with dimensions of $500 \mathrm{~mm} \times 500 \mathrm{~mm}$ with $40 \mathrm{~mm}$ thickness were used to test thermal conductivity in conformity with TS EN ISO 10456 and ISO 8302. Test samples were water-cured until the test age and then removed and air-cured for 24 hours before testing. The heat was applied through the lower part of the equipment that was set to $40^{\circ} \mathrm{C}$ whilst upper part was set to $20^{\circ} \mathrm{C}$ to maintain temperature difference $\left(\Delta \mathrm{T}=20^{\circ} \mathrm{C}\right)$ for all mixes. Thermal conductivity test equipment is given in Fig.3. Samples were surrounded with polystyrene foam to prevent heat loss and gain from the surrounding environment. A representative thermal conductivity value (l) was recorded through the instrument based on Equation 1 below.

$$
\text { Equation 1: } K=\frac{Q \cdot L}{A \cdot \Delta T}
$$

K: $\quad$ Thermal conductivity (W/ m.K)

Q: $\quad$ Power to generate temperature difference (Watts)

L: $\quad$ Sample thickness $(\mathrm{m})$

A: $\quad$ Area of surface $\left(\mathrm{m}^{2}\right)$

$\triangle \mathrm{T}$ Temperature difference 


\subsubsection{Sound Permeability}

Providing a better quality of life of the occupants is one of the challenges in the built environment under the national legislations and Green Building tools (World Green Building Council, 2020) in recent times. Improving the indoor ambient noise levels through building fabric should be at desired (30-45 dB) levels (WHO, 1999). Concrete inherent properties could provide improved acoustic performance and improve sustainability credentials from the social perspective. In this study, the performance of the sound permeability of produced mixes was tested using $500 \mathrm{~mm}$ x $500 \mathrm{~mm}$ square samples. Samples had a thickness of $40 \mathrm{~mm}$. After demoulding, specimens were watercured until the test age. Prior to testing, samples were taken out from the water curing and left to air-drying for 24 hours. Sound permeability test equipment is given in Fig.4. The sound was applied for an hour through a speaker mounted at the bottom of the test equipment and the value was recorded in decibels. The test sample was subsequently placed on top of it and the sound received during the testing was obtained in decibels. Sound permeability value was calculated in percentage based on given and received sound decibels. The test sample was covered with polystyrene foam to prevent any interference.

\section{Results and Discussion}

\subsection{Engineering Properties}

\subsubsection{Slump Test}

Slump values reported are shown in Fig. 5. As expected, slump values lowered as the design strength increased due to a decrease in the $\mathrm{w} / \mathrm{b}$ ratio. It can be also seen from the results that the WA addition did not have any adverse effect on the slump of both concrete mixes. Results are consistent with earlier studies (Cheah \& Ramli, 2012; Udoeyo, Inyang, Young, \& Oparadu, 2006; Elinwa \& Mahmood, 2002) but in contrast with earlier research by Luz Garcia (da Luz Garcia, 2013) who reported improvement in a slump when 5\% WA was used. 45-WA mix with higher WA content had a similar slump as the 45-PC mix. This slight reduction of 30-WA might be due to the higher amount of coarse aggregates used could have increased the friction amongst the constituents. The author believes that replacing PC with WA could have potentially reduced the number of finer particles and thereby diminished the requirement for water content at this very early stage. Results suggest that WA use in high strength $(\mathrm{C} 35 / 45)$ applications could be done similar to conventional concrete. However, use of WA concrete in medium strength $(\mathrm{C} 25 / 30)$ application could require higher admixture content for the same consistency and thereby higher cost. This could negatively affect the environmental and economic sustainability associated with increasing the amount of admixture required.

\subsubsection{Bulk Density}

Bulk density values of mixes are given in Fig. 6. It can be seen from the results that WA incorporation increased bulk density by $0.99 \%$ and $0.21 \%$ for $30 \mathrm{MPa}$ and $45 \mathrm{MPa}$ design strength mixes respectively. A similar finding of a $0.66 \%$ increase was reported earlier by Ban (Cheah \& Ramli, 2012). Pavlikova (Pavlikova, et al., 2018) also found an increase of $1.23 \%$ for $10 \%$ WA added concrete. However, contradicting results are also noted (Chowdury, Mishra, \& Suganya, 2015; Cheah \& Ramli, 2011; Kizinevic \& Kizinevic, 2016). Higher bulk density of WA mixes might be linked with the higher $\mathrm{K}_{2} \mathrm{O}$ content of WA as seen in Table 1 which potassium $(\mathrm{K})$ is believed to increase the rate of reactivity with the presence of water at the early phase. This led to increase in the formation of hydration products and led to higher bulk density. This is also supported by the early compressive strength results. From the sustainability perspective, increase in the bulk density could potentially lead to increased dead load for structural applications. This may require more reinforcement to withstand the exposed loads which will have a negative impact on environmental and economic sustainability.

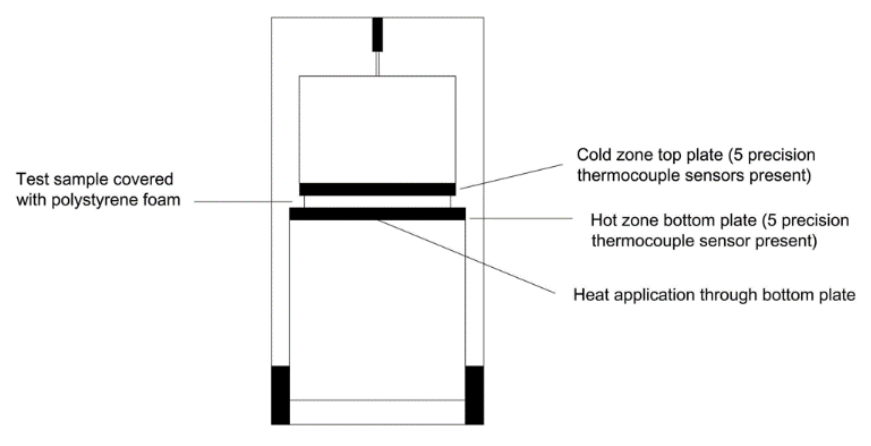

Figure 3. Thermal conductivity test equipment

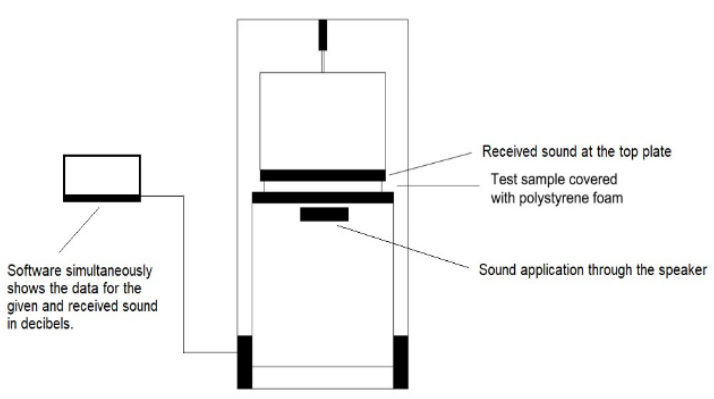

Figure 4. Sound permeability test equipment

Table 5. Environmental Impacts for the Production of Constituents Used

\begin{tabular}{l|c|c}
\hline Stage & Constituents & eCO2 emissions \\
\hline \multirow{3}{*}{ Production } & Aggregates & $* 0.005^{(1)}($ Hammond \& Jones, 2011) \\
\cline { 2 - 3 } & Portland cement & $* 0.710^{(1)}($ Hammond \& Jones, 2011) \\
\cline { 2 - 3 } & Water & $* 0.000155$ \\
\cline { 2 - 3 } & Admixture & $* 0.0022$ \\
\hline
\end{tabular}




\begin{tabular}{l|c|c}
\hline \multirow{3}{*}{ Transportation } & $\begin{array}{c}\text { Portland cement (through mainland } \\
\text { transportation) }\end{array}$ & $\begin{array}{c}* 0.32^{(2 \& 3)} \text { (International Maritime } \\
\text { Organization, 2014; Rossit \& Lawson, } \\
2012)\end{array}$ \\
\cline { 2 - 3 } & $\begin{array}{c}\text { Portland cement (through seaway } \\
\text { transportation) }\end{array}$ & $\begin{array}{c}* 0.007^{(2 \& 3)} \text { (International Maritime } \\
\text { Organization, 2014; Rossit \& Lawson, } \\
2012)\end{array}$ \\
\cline { 2 - 3 } & Admixture & $* 0.138$ \\
\hline
\end{tabular}

(1) Bath Inventory (Hammond \& Jones, 2011); (2) International Maritime Organization (International Maritime Organization, 2014); (3)Rossit, G. \& Lawson, M. (Rossit \& Lawson, 2012); * represents the data obtained from the relevant bodies and scientific references. *Water relevant emissions were based on the national tariff in North Cyprus; admixture-related emissions were established based on the delivery conditions; and emissions through aggregates extraction and transportation was calculated by considering the distance between the extraction and the production site in cooperation with a local concrete company. For wood ash use, emissions due to electricity generation are $0.164 \mathrm{~kg} \mathrm{CO}_{2}$ per 1 hour of sieving. This value is neglected as it has an insignificant effect on eCO $\mathrm{Cmissions}_{2}$ Transportation emissions of $\mathrm{WA}$ were calculated as $9.3 \mathrm{~kg} \mathrm{CO}_{2}$ per trip.

Table 6. Highway Transportation Distances and Costs of Constituents

\begin{tabular}{l|c|c|c}
\hline \multirow{2}{*}{ Constituents } & Haulage distance (km) & \multicolumn{2}{|c}{ Cost (\$/tonne) } \\
\cline { 3 - 4 } & & Production & 3.21 \\
\hline Aggregates & 72.5 & 4.46 & 4.46 \\
\hline PC & 116.5 & 89.29 & 3.28 \\
\hline Admixture & 57 & 0.064 & 625 \\
\hline
\end{tabular}

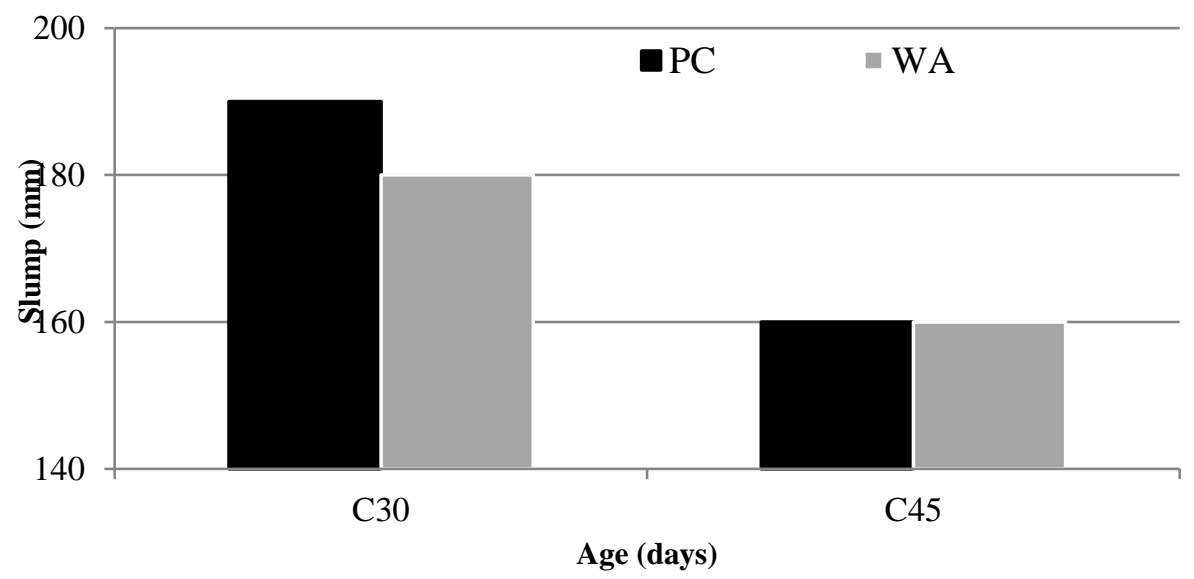

Figure 5. Slump Test Results

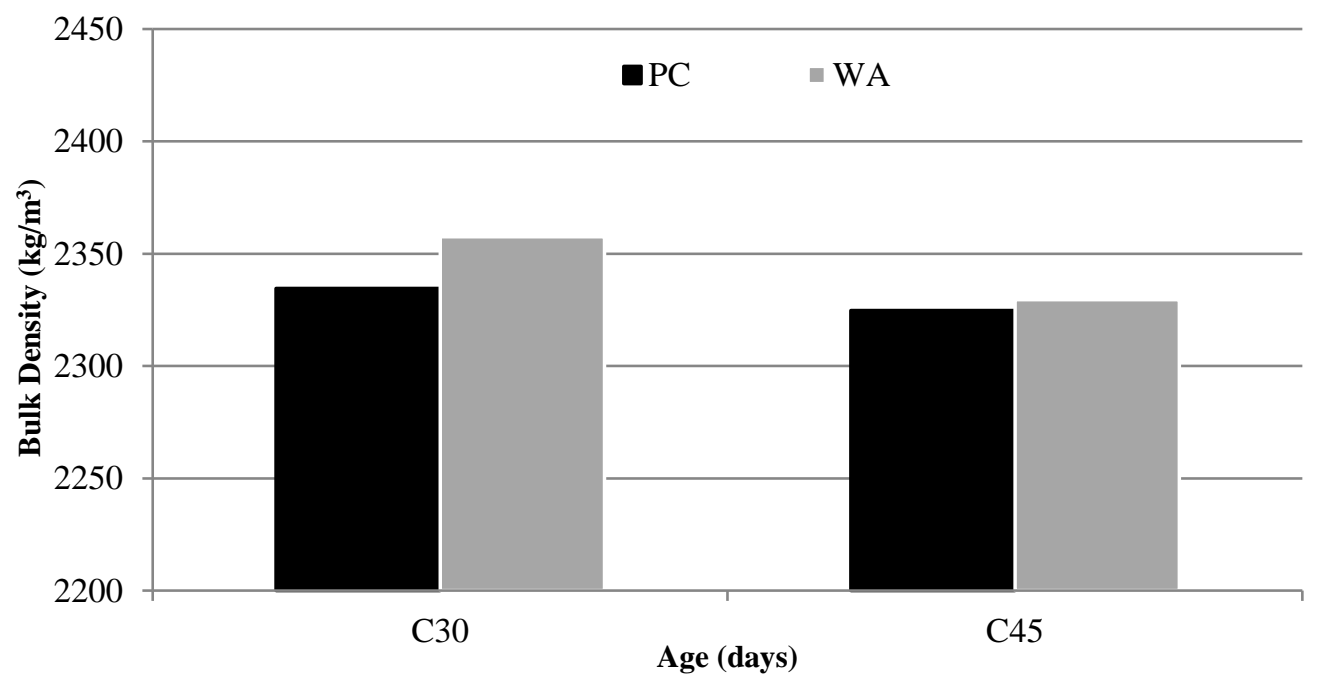

Figure 6. Bulk Density Results 


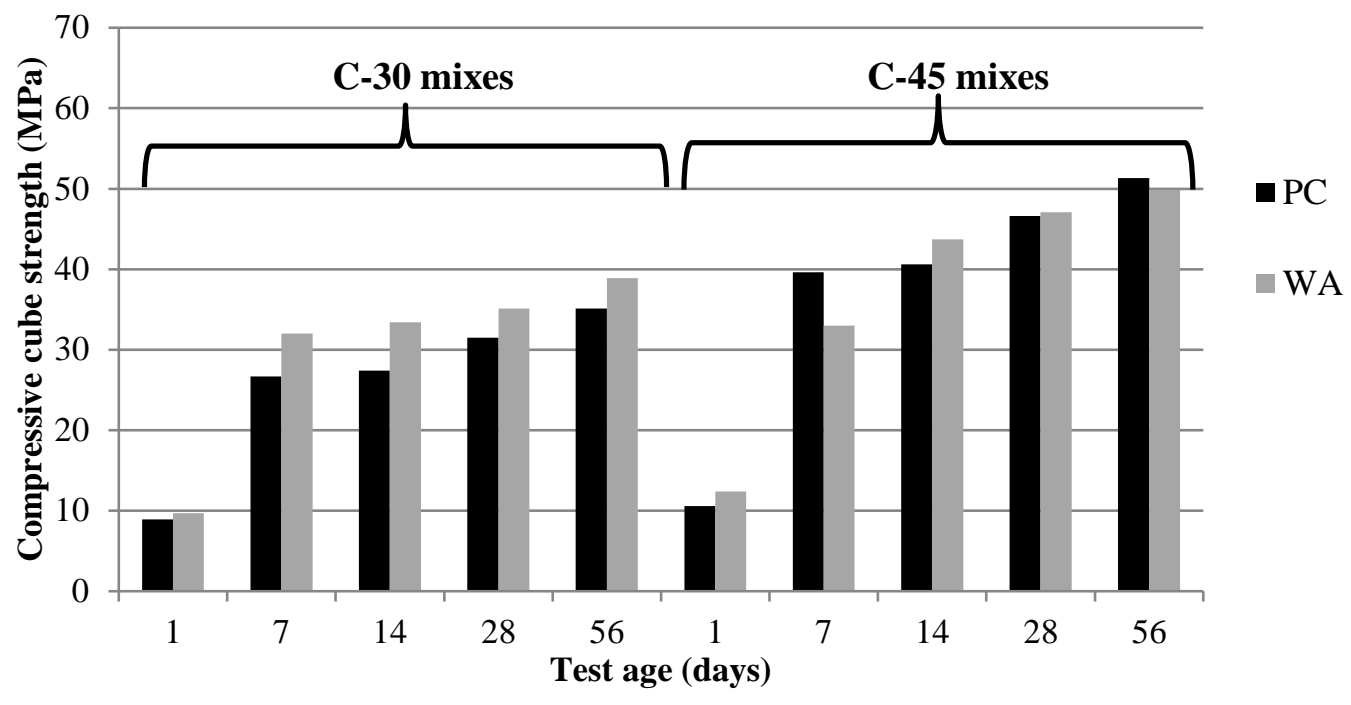

Figure 7. Compressive Cube Strength Development of PC and WA Mixes

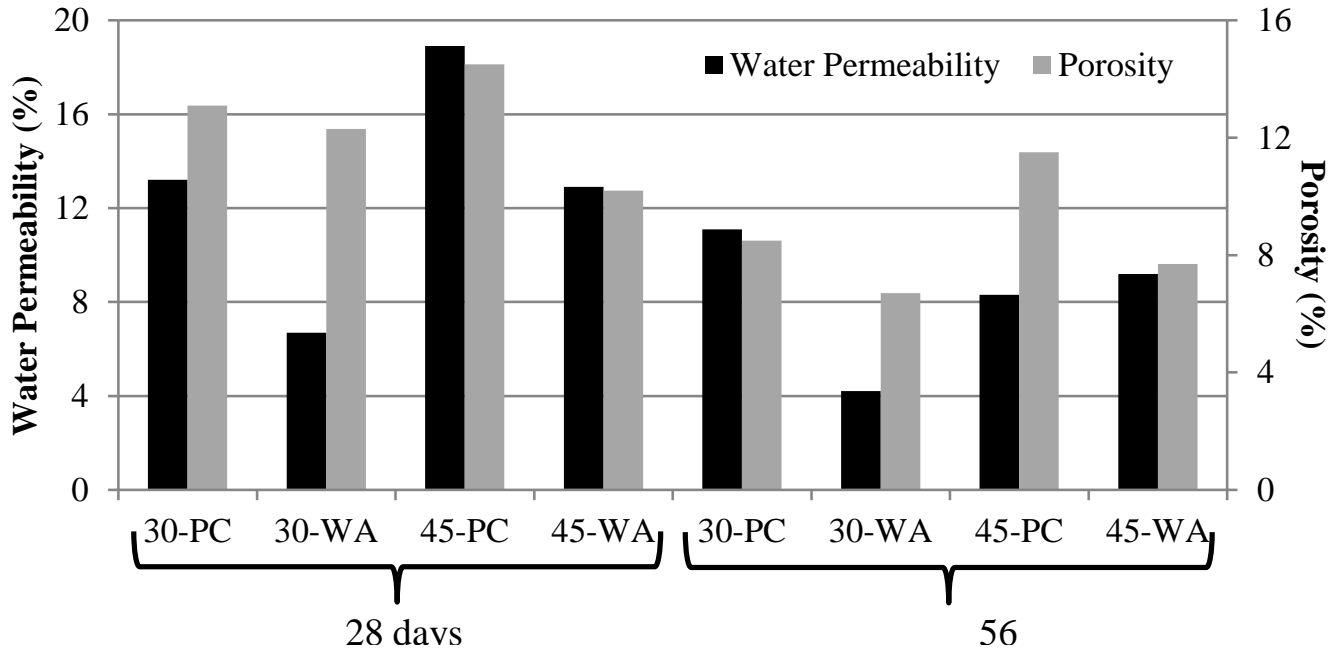

Figure 8. Water Permeability and Porosity Values of Developed Mixes

\subsubsection{Compressive Strength}

Compressive cube strength values are revealed in Fig. 7. Early strength evaluations were performed on $1 \mathrm{~d}$ and $7 \mathrm{~d}$. Mixes were tested at $14 \mathrm{~d}$ and $28 \mathrm{~d}$ to monitor whether the target design strength is fulfilled. In addition, compressive strength test was also done at $56 \mathrm{~d}$ to check the presence of pozzolanic reaction at post 28 d. No specific trend was observed for WA mixes. However, mix designs were found to influence the compressive strength of WA mixes. 30-WA mix was associated with an increase in compressive cube strength while quite similar compressive strength results were observed for the WA-45 mix. Strength development results were consistent with Luz Garcia (da Luz Garcia, 2013) who reported higher strength developments were reported at a very early age $(3 \mathrm{~d})$. As discussed in previous section, higher $\mathrm{K}_{2} \mathrm{O}$ content of WA may have increased the rate of hydration at $1 \mathrm{~d}$. However, this was followed by lower compressive strength values for mixes containing WA which may be due to lower $\mathrm{CaO}$ and $\mathrm{SiO}_{2}$ contents in WA compared to PC.
In addition, $28 \mathrm{~d}$ results are coherent with a previous study (Cheah \& Ramli, 2011) which also reported similar compressive cube strengths at 5\% WA replacement. WA particles were coarser compared to PC particles. This increment in the compressive strength could be due to WA acting as a bridge between the higher amount of coarse aggregate, compared to $45 \mathrm{MPa}$ design strength mixes, and finer constituents and hence providing a denser matrix. This trend was not observed for 45-WA mixes due to the lower content of coarse aggregates. Kalra and Mehmood (Kalra \& Mehmood, 2018) also reported that stiffer aggregate could produce stiffer concrete mix. This weakens the bond between the cement paste and the aggregates and results in lower strengths at early ages $(<7 \mathrm{~d})$. This was compensated at the later ages when either slightly lower or similar results were recorded. This refinement is believed to be due to the pozzolanic characteristics of WA. In general, the results agree with previous studies (Cheah \& Ramli, 2011; Chowdury, Maniar, \& Suganya, 2015; Udoeyo, Inyang, Young, \& Oparadu, 2006) which indicated a 5\% WA use did not have any remarkable negative influence on the 
compressive cube strength. Nevertheless, it is in contrast with earlier studies (da Luz Garcia, 2013; Cheah \& Ramli, 2011) which claimed that WA has non-glassy properties and acts as filler rather than having a pozzolanic property. From the environmental sustainability perspective, WA use did not have any adverse impact. Similar strength values with slightly reduced PC content could provide economically-efficient concrete production.

\subsubsection{Water Permeability and Porosity}

Water permeability and porosity test results at $28 \mathrm{~d}$ and $56 \mathrm{~d}$ are shown in Fig. 8. Lower water absorption values were found for WA mixes except for 45 -WA at $56 \mathrm{~d}$. The results were similar to compressive cube strength results, showing that WA mixes performed slightly higher compressive cube strengths except for 45-WA mix with slightly lower compressive strength. Test results showed a reduction from $28 \mathrm{~d}$ to $56 \mathrm{~d}$. Compared to $30 \mathrm{MPa}$ target design strength mixes, $45 \mathrm{MPa}$ target design strength mixes had higher water permeability and porosity results which was not expected. This is believed to be better distribution of constituents for $30 \mathrm{MPa}$ target design strength mixes compared to $45 \mathrm{MPa}$ target design strength mixes. Permeability values were $13.2 \%$ and $11.1 \%$ for $30-\mathrm{PC}$ and $5.7 \%$ and $4.2 \%$, for $30-\mathrm{WA}$ mix at $28 \mathrm{~d}$ and $56 \mathrm{~d}$, respectively. Lower water permeability values of 30 -WA mixes could be explained by better particle packing, as stated earlier based on compressive cube strength results. In addition, 45-PC water permeability values were $18.9 \%$ and $9.3 \%$ while values for $45-\mathrm{WA}$ were $14.5 \%$ and $9.2 \%$ at 28 and $56 \mathrm{~d}$ respectively. An earlier study by Prabagar (Prabagar, Subasinghe, $\&$ Fonseka, 2015) also reported a decrease in water permeability up to $20 \%$ WA content at $21 \mathrm{~d}$. On the contrary, existing studies found that 5\% WA content increased water absorption by $0.4 \%$ (Udoeyo, Inyang, Young, \& Oparadu, 2006) and approximately 2\% (Kizinevic \& Kizinevic, 2016).

WA use reduced the porosity of concrete mixes as seen in Fig. 8. WA is thought to be coarser compared to PC; therefore, this could be due to refinement of macro-pores through WA addition. Porosity values decreased between $28 \mathrm{~d}$ and $56 \mathrm{~d}$ due to the hydration process leading to a denser matrix, as suggested by the compressive cube strength results. Moreover, Pavlikova (Pavlikova, et al., 2018) also found reduction in porosity for WA content of $10 \%$ with a value of $13.6 \%$. In this research, a considerably lower porosity value of $6.7 \%$ was obtained for 30 WA whereas 45-WA porosity had a similar value of $14.5 \%$. Prabagar (Prabagar, Subasinghe, \& Fonseka, 2015) reported pore refinement in the matrix for WA mix. Results might suggest better permeability for WA mixes, thus this could increase service life of concrete structure and lead to environmental and economic efficient production.

\subsection{Sustainability Analyses}

\subsubsection{Environmental Sustainability}

The $\mathrm{eCO}_{2}$ emissions of produced mixes are presented in Fig. 9. The $\mathrm{eCO}_{2}$ emissions were $343.7 \mathrm{~kg} \mathrm{CO} / \mathrm{m}^{3}$ and $422.9 \mathrm{~kg}$ $\mathrm{CO}_{2} / \mathrm{m}^{3}$ for $30-\mathrm{PC}$ and $45-\mathrm{PC}$ concrete mixes respectively. The use of WA reduced $\mathrm{eCO}_{2}$ emissions by $1.7 \%$ and $2.2 \%$ for $30-\mathrm{WA}$ and 45-WA mixes, respectively. This reduction was due to replacing higher energy and $\mathrm{CO}_{2}$ intensive $\mathrm{PC}$ by a waste material of WA. WA transportation distance was $57 \mathrm{~km}$. Even though emissions through transportation were included in the calculations, minor reductions were achieved. The $\mathrm{eCO}_{2}$ emissions reductions could be maximized by up to $4.4 \%$ for both WA mixes if the transportation emissions were not considered by using only 5\% WA content. The results were in agreement with the previous study (Pavlikova, et al., 2018) that reported a 7.2\% reduction in emissions at $10 \% \mathrm{WA}$. It could be stated that WA could be utilized in concrete production because $\mathrm{PC}$ is a high $\mathrm{eCO}_{2}$ intensive material. Accordingly, replacing PC with 5\% WA on a mass basis could still be environmentally feasible if obtained with lightweight duty vehicle (with $163.7 \mathrm{~g} \mathrm{CO}_{2} / \mathrm{km}$ ) from 91.7 $\mathrm{km}$ and $114.6 \mathrm{~km}$ distances for $30-\mathrm{WA}$ and 45-WA mixes respectively. This increase was due to the amount of WA increasing from $20 \mathrm{~kg} / \mathrm{m}^{3}$ to $25 \mathrm{~kg} / \mathrm{m}^{3}$. Thus, it is important to consider using WA for mass production to maximize its environmental benefits. Allocation of $\mathrm{eCO}_{2}$ emissions through transportation and production is shown in Fig. 10. Production percentage increased as the concrete target design strength increased due to the increase in the PC content. WA use contributed to overall $\mathrm{eCO}_{2}$ emissions by $9.3 \mathrm{~kg} \mathrm{CO} / \mathrm{CO}^{3}$. Concerning emissions from transportation, emissions increased by $2.8 \%$ and $2.4 \%$, for $30-\mathrm{WA}$ and $45-\mathrm{WA}$, respectively, compared to conventional mixes. The results suggested that if recycling facilities were located closer to the concrete production site, transportation emissions could be either minimized or eliminated. Cumulative collection of WA could increase its availability and this will encourage industry to utilize WA in mass concrete production. Thus, local regional bodies should integrate carbon emissions reduction policies and consider solid waste collection for the promotion of sustainable development.

The relationship between the $\mathrm{eCO}_{2}$ emissions and $28 \mathrm{~d}$ compressive cube strengths of mixes are represented in Table 7. WA mixes release lower $\mathrm{eCO}_{2}$ emissions compared to $\mathrm{PC}$ mixes to achieve $1 \mathrm{MPa}$. However, values of $9.6 \mathrm{~kg} \mathrm{CO} / \mathrm{MPa}$ and 8.8 $\mathrm{kg} \mathrm{CO}_{2} / \mathrm{MPa}$ for 30-WA and 45-WA, respectively, are quite higher compared to those reported earlier (Pavlikova, et al., 2018) which found $7.7 \mathrm{~kg} \mathrm{CO}_{2} / \mathrm{MPa}$ and $6.7 \mathrm{~kg} \mathrm{CO}_{2} / \mathrm{MPa}$ for control and $10 \%$ WA mixes. This is believed to be due to the lack of natural raw materials required their importations from abroad and $\mathrm{eCO}_{2}$ emissions associated with their transportation rose up accordingly. 


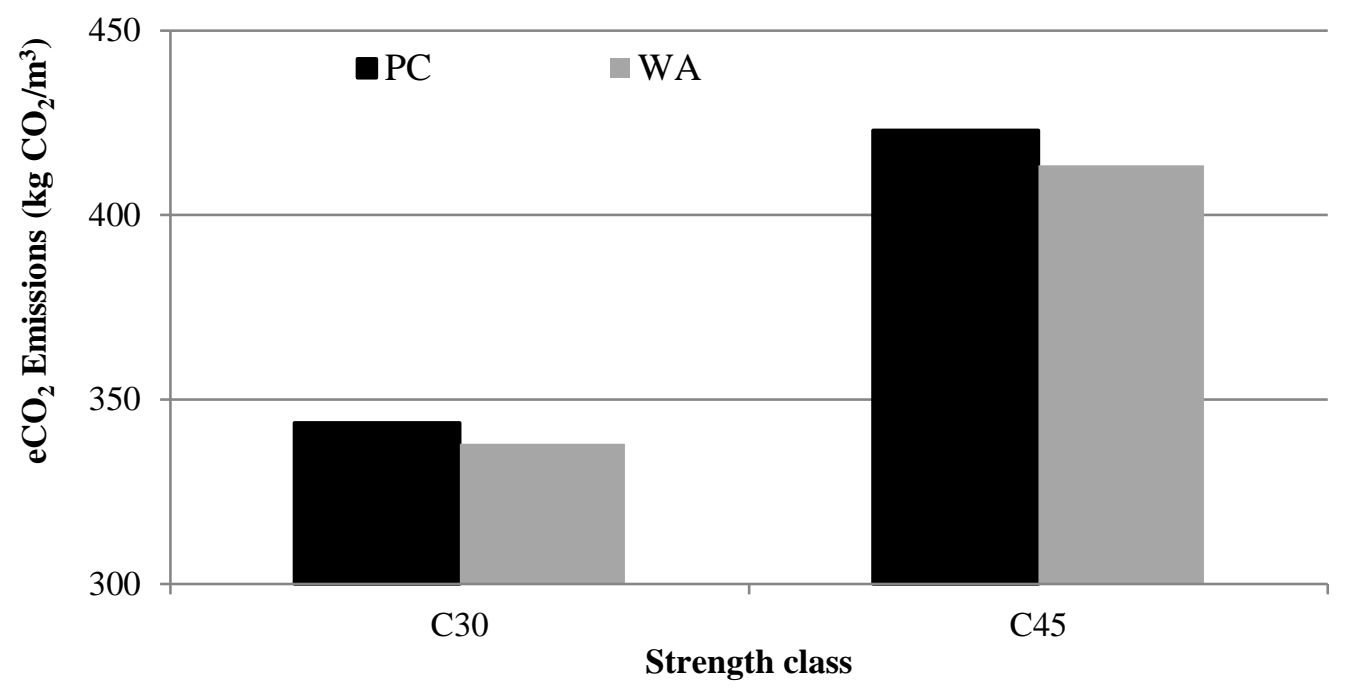

Figure 9. The eCO Emissions of Developed Mixes

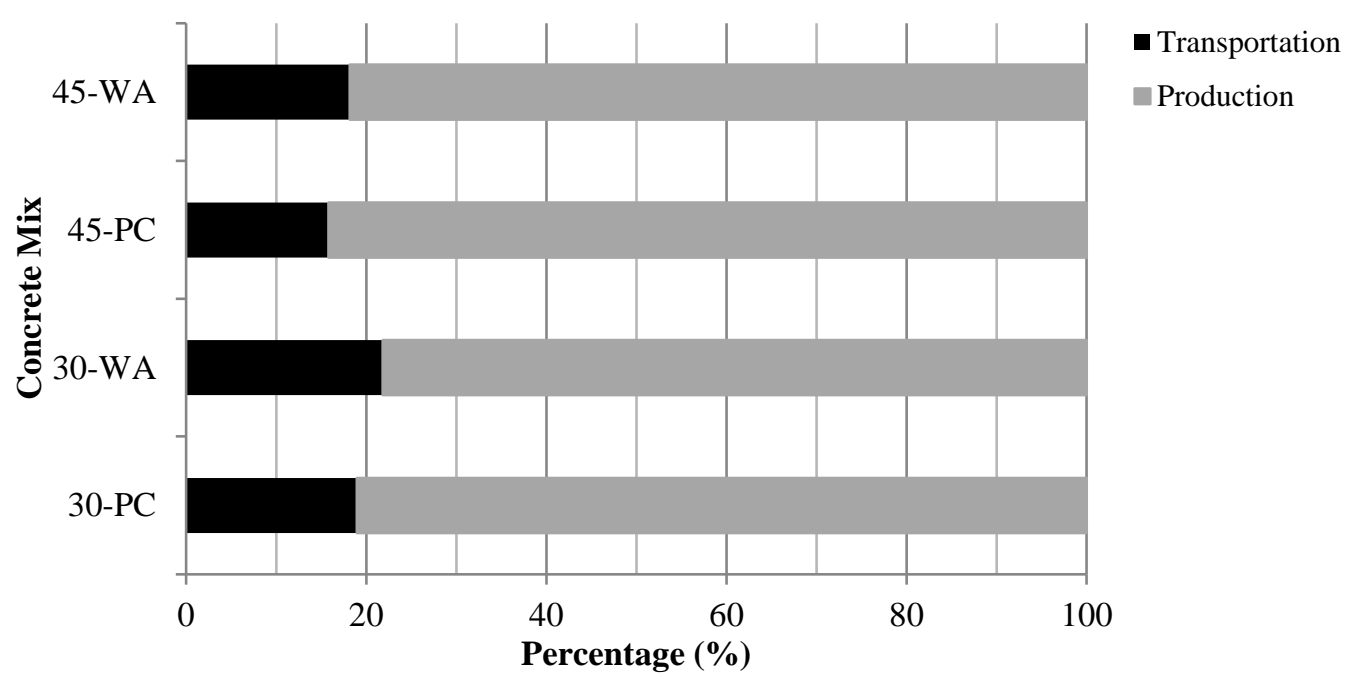

Figure 10. Allocation of the e $\mathrm{CO}_{2}$ Emissions of Developed Mixes Through Transportation and Production

Table 7. The Relationship Between Environmental and Economic Sustainability and 28d Compressive Strength

\begin{tabular}{|c|c|c|c|}
\hline Design Strength (MPa) & Concrete Mix & $\begin{array}{c}\text { Environmental impact / } 28 \\
\text { d strength } \\
(\mathrm{kg} \mathrm{CO} / \mathrm{MPa}) \\
\end{array}$ & 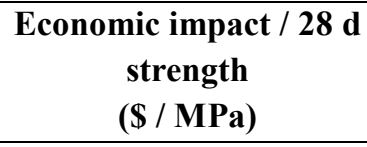 \\
\hline \multirow[t]{2}{*}{30} & $\mathrm{PC}$ & 10.9 & 1.5 \\
\hline & WA & 9.6 & 1.3 \\
\hline \multirow[t]{2}{*}{45} & $\mathrm{PC}$ & 9.1 & 1.2 \\
\hline & WA & 8.8 & 1.1 \\
\hline
\end{tabular}




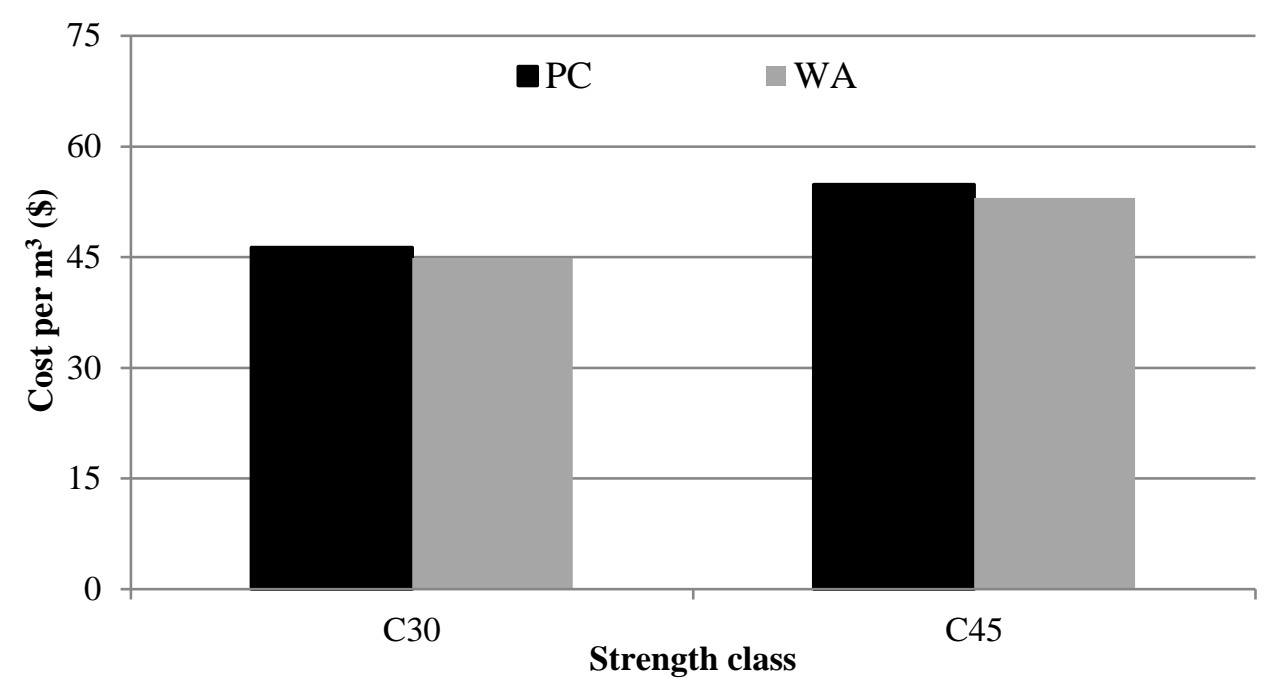

Figure 11. Cost of Mixes Developed

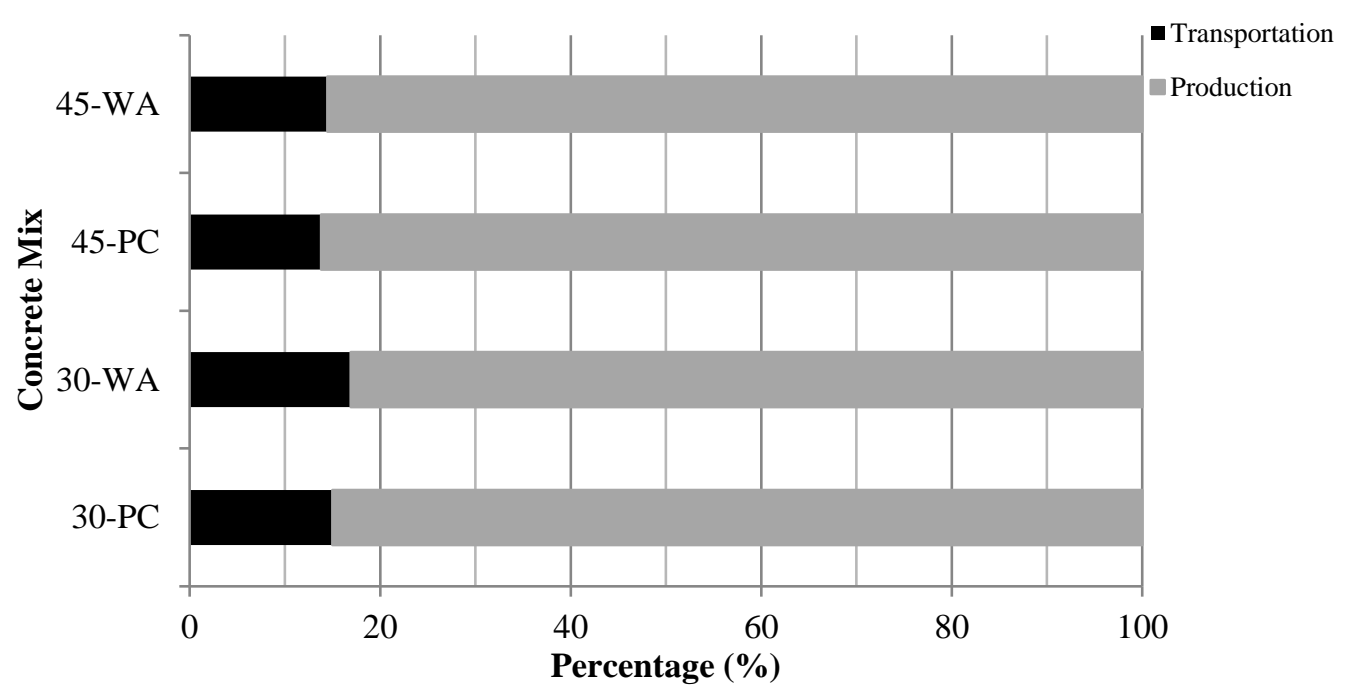

Figure 12. Distribution of Cost of Developed Mixes Through Transportation and Production

\subsubsection{Economic Sustainability}

Costs of produced concrete are expressed in Fig. 11. It is clear from the results that WA incorporation reduced the overall cost by $3.2 \%$ and $3.4 \%$ for $30-\mathrm{WA}$ and $45-\mathrm{WA}$ mixes, respectively, compared to the PC mixes. Earlier research by Cheah (Cheah \& Ramli, 2012) also reported cost reduction when using WA. In addition, the distribution of the cost of produced mixes through transportation and production is shown in Fig. 12. It is seen that the production process of WA mixes had higher cost due to transportation compared to PC mixes. This is due to delivering WA from longer distances, which contributes to higher emissions through transportation. Moreover, replacing PC with a cost-free WA waste led to a reduction of cost through production. The results showed that WA use could be an economically-efficient practice if being delivered from a distance of $83.6 \mathrm{~km}$ and 90.1 $\mathrm{km}$ for 30-WA and 45-WA mixes, respectively, based on lightduty vehicle consuming 6.4 litres of petrol per $100 \mathrm{~km}$. Table 7 reveals the relation between the costing and $28 \mathrm{~d}$ strength of developed concretes. WA addition had lower cost of mixes per 1 $\mathrm{MPa}$ for both strength classes.

\subsubsection{Social Sustainability}

\subsubsection{Sound Permeability}

Sound permeability values and index reduction of impact noise are presented in Table 8. It is seen that WA incorporation reduces the sound permeability property of concrete mixes. The results are consistent with an earlier study (Bostanci, 2019). It is also reported earlier (Arenas, et al., 2011) that total surface area, pore diameter, shape and texture of aggregates and micropores determine the sound absorption of concrete. WA use reduced the total surface area and thereby sound permeability. The reduction index of impact noise results was consistent with the range (17$22 \mathrm{~dB}$ ) defined earlier (Desarnaulds, Costanzo, Carvalho, \& Arlaud, 2005) for sheep wool, wood wool and cellulose materials. 
The relation between sound permeability and porosity is given in Fig. 13. Both PC and WA mixes showed good correlation between permeability and porosity, having values of $\mathrm{R}^{2}=0.98$ and $\mathrm{R}^{2}=0.90$ respectively. Recent building assessment tools pay attention to acoustically effective construction materials to enhance the occupants` life quality, and thus, WA use in concrete production could be a potential contribution in this respect.

\subsubsection{Thermal Conductivity}

Table 9 gives the thermal conductivity values of the laboratory mixes. No clear trend was observed for thermal conductivity test results. Higher thermal conductivity values were found for PC mixes except for 30-PC at $28 \mathrm{~d}$. Khaliq (Khaliq \& Kodur, 2011) stated that a higher amount of chemical admixtures may increase dissolved chemical ions in water and increase thermal conductivity. An earlier study by Venkataraman (Venkataraman, Mishra, \& Militky, 2017) stated that material density, moisture content and ambient temperature could affect the thermal conductivity of concrete. An increase in thermal conductivity for $30-\mathrm{WA}$ at $28 \mathrm{~d}$ could be explained by either ambient temperature during air drying or higher bulk density compared to conventional mix. It is also consistent with Prabagar (Prabagar, Subasinghe, \& Fonseka, 2015) and Pavlikova (Pavlikova, et al., 2018) who stated that $15 \%$ and $10 \%$ WA addition could contribute to higher thermal conductivity. It is also noteworthy to mention that values obtained from thermal conductivity test was higher than the values reported by Pavlikova (Pavlikova, et al., 2018) which were $1.90 \mathrm{~W} / \mathrm{m} . \mathrm{K}$ and 1.79 $\mathrm{W} / \mathrm{m} . \mathrm{K}$, for compressive strengths of $64.5 \mathrm{MPa}$ and $58.4 \mathrm{MPa}$, and mixes with $10 \%$ and $15 \%$ WA respectively. WA mixes had lower values compared to PC mixes at $56 \mathrm{~d}$. It is believed that the contribution of pozzolanic reactions improved pore structure and lowered thermal conductivity between $28 \mathrm{~d}$ and $56 \mathrm{~d}$. Test results for $56 \mathrm{~d}$ contribute to the literature on the thermal conductivity performance of WA mixes since the existing studies have assessed the thermal conductivity performance of WA mixes at $28 \mathrm{~d}$. In addition, Demirboga (Demirboga, 2007) stated that lower thermal conductivity could be linked with the lower thermal conductivity of minerals with amorphous characteristics. Thermal conductivity values increase as the target strength increased. This is consistent with Ngohpok (Ngohpok, Satiennam, Klungboonkrong, \& Chindaprasirt, 2018) who reported higher thermal conductivity as the filling paste ratio advanced. In general, WA could be potentially used for sustainable construction practices to increase thermal resistance and maintain the thermal comfort of the occupants as well as decrease energy demand.

\subsubsection{Overall Sustainability Perspective}

Environmental, economic and social facets of sustainability are interconnected with each other in that the success of sustainability is based on the integration of all three facets. From the traditional application perspective, the usual trend includes the use of PC for most of the applications. Partial incorporation of WA in concrete production could slightly reduce the demand for $\mathrm{PC}$ use and, thereby the environmental footprint of concrete. It is worthy to consider that the global PC content has reached approximately 3 billion tons (Timperley, 2018). Huising (Huising, Zhang, Moore, Qiao, \& Li, 2015) stated that $90 \%$ of these emissions were generated through clinker use. The use of WA could also reduce the contribution of $\mathrm{eCO}_{2}$ emissions to greenhouse gases associated with concrete production and thereby to global warming. Cyprus is one of the countries that will be affected directly due to its geographical location. If the level of greenhouse gases is maintained, the average temperature is expected to increase between $1^{\circ} \mathrm{C}$ and $3^{\circ} \mathrm{C}$ in the following decades, which will also reduce the amount of rainfall (The Cyprus Institute, n.d.). This will increase the energy demand especially in hot weather conditions, and reduce agricultural production due to lower rainfall. The reduction in water sources may increase the water prices, which could affect economic and social sustainability and threaten the living habitat in Cyprus. Reduced availability of natural raw in the future and the increased price of water will inevitably increase the cost of concrete, reducing the affordability of construction. From both environmental and economic perspectives, earlier studies (Prabagar, Subasinghe, \& Fonseka, 2015; Siddique, 2012; Cheah $\&$ Ramli, 2011) stated that disposal of waste materials will be a global concern due to the limited availability of virgin lands for disposal. Since Cyprus is a small island with limited lands will be of significant concern and a governmental priority in the near future. This will eventually force the government to increase tax for the disposal of waste materials which will require proper disposal strategy on national and international basis. Previous research by Huising (Huising, Zhang, Moore, Qiao, \& Li, 2015) suggested the need for societal radical transformation towards a low carbon economy by implementing suitable climate policies. The use of WA in concrete production could contribute to social, environmental and economic sustainability by preventing waste material from being sent to landfill, decreasing the amount of natural raw materials used and thereby maintaining the overall cost of the concrete. Furthermore, Cheah (Cheah \& Ramli, 2011) stated that WA could result in contamination of ground water through leaching of heavy metals from rain, posing a risk to health due to airborne of WA under windy conditions. These risks will be minimized if WA is handled, stored and used responsibly in concrete production.

Table 10 gives the optimum distances to environmentallyfriendly and cost-effective concrete production. The results showed that WA use could be a sustainably feasible approach for reducing the total $\mathrm{PC}$ content and thereby natural raw materials associated with its production to lower $\mathrm{eCO}_{2}$ emissions of concrete if they can be supplied from distances of up to $91.7 \mathrm{~km}$ and $83.6 \mathrm{~km}$ for $30-\mathrm{WA}$ and $45-\mathrm{WA}$, respectively. The results of this study showed that WA use could maximise sustainability performance if greater replacement levesl are used. The results also suggest that the WA incorporation could promote sustainable concrete production.

\subsection{Effect of Wood Ash on Concrete}

Considering the results of the tests conducted, WA have varying effect on concrete properties through its chemical and physical properties. Even though WA has coarser particle size as revealed in Fig. 1, WA is believed to provide better uniform distribution and act as a bridge between finer and coarser constituent particles. This is believed to improve interfacial transition zone (ITZ) and lead to more compact structure. Due to its compact characteristics, porosity property of WA mixes was reduced. This is more obvious in C45 mix compared to C30 mix which fine and coarse aggregate contents have quite similar closer quantities. Even though WA had lower $\mathrm{CaO}$ and $\mathrm{SiO}_{2}$ contents, increased ITZ could be attributed to increased Calcium Silicate Hydrate gel at early stage through more uniform characteristics and increased reactivity rate due to higher content of $\mathrm{K}_{2} \mathrm{O}$. This 
was observed to increase the density. Improved ITZ could potentially improve durability which is a function of sustainability. Thus, WA addition could lead to increased service life through enhanced durability. On the contrary, coarser particle size of WA slowed down the rate of pozzolanic activity at post 14 d. WA incorporation, as a consequence, results in increase in thermal conductivity and sound permeability.

\section{Conclusions and Recommendations}

Scientific knowledge on the waste incorporated concrete production is crucial for the promotion of sustainable development. The results obtained could reveal technical information on the feasibility of concrete mixes made with $5 \%$ WA from the basic engineering and sustainability perspectives. The main conclusions of this study are expressed below;

- WA addition could achieve similar performances as conventional PC mix. Slump properties indicate that WA use does not require extra water content and superplasticizer to achieve target workability.

- WA incorporation increased the bulk densities by $0.99 \%$ and $0.21 \%$ for 30 -WA and $45-\mathrm{WA}$ respectively.

Two different trends were found for compressive cube strength developments for 30-WA and 45-WA mixes. The results suggest that mix proportioning has an important effect on the efficiency of WA. WA use achieved similar compressive cube strengths at both $7 \mathrm{~d}$ and $28 \mathrm{~d}$ for both mixes. Compressive strength gains ranged from $9 \%$ to $22 \%$ for $30-\mathrm{WA}$ mix while losses and gains for 45 -WA mix were between $-17 \%$ and $17 \%$ from $1 \mathrm{~d}$ to $56 \mathrm{~d}$.

- Tests investigating social sustainability related properties showed that WA could be used to create acoustically and thermally effective concrete applications for better health and well-being of the occupants.

30-WA mix had lower water permeability and porosity while similar results were obtained for 45-WA mix compared to conventional PC mixes. Both PC and WA mixes had strong correlations between water permeability and porosity properties.

- WA mixes could decrease $\mathrm{eCO}_{2}$ emissions by $1.7 \%$ and $2.2 \%$, and overall cost by $3.2 \%$ and $3.4 \%$, for $30-\mathrm{WA}$ and 45-WA mixes respectively, compared to PC mixes. The results of this study revealed that WA mixes could be environmentally and economically feasible approach if obtained from $83.6 \mathrm{~km}$ and $90.1 \mathrm{~km}$ distances.

- It is important to point out that this study reviews concrete strength classes of C30 and C45. Other concrete classes and higher replacement levels for WA in concrete are further recommended to be investigated.

It is also recommended by the author that WA having different particle sizes should be also investigated in concrete production to monitor the effect of WA particle size on concrete properties.

WA use could be a more feasible approach from the sustainability perspective if carbon reduction policies are put into action.

\section{Acknowledge}

The author would like to express his gratitudes to individuals; Mrs. Tuğçe Mani, Kemal Sergen and Metin Eray, and companies; Boğaziçi Endüstri Madencilik Ltd. and KASCON Ready-mix Concrete Company and Nayat Yapı Ltd. for their contribution to this research.

\section{References}

Abbasi, M., \& Nilsson, F. (2016). Developing environmentally sustainable logistics: Exploring themes and challenges from a logistics service providers' perspective. Transportation Research Part D: Transport and Environment, 273-283. https://doi.org/10.1016/j.trd.2016.04.004.

Abdullahi, M. (2006). Characteristics of Wood ASH/OPC Concrete. Leonardo Electronic Journal of Practices and Technologies, 9-16.

Akadiri, P., Chinyio, E., \& Olomolaiye, P. (2012). Design of A Sustainable Building: A Conceptual Framework for Implementing Sustainability in the Building Sector. Buildings, $126-152$ https://doi.org/10.3390/buildings2020126.

Alyamac, K. E., Ghafari, E., \& Ince, R. (2017). Development of eco-efficient self-compacting concrete with waste marble powder using the response surface method. Journal of Cleaner Production,

192-202. https://doi.org/10.1016/j.jclepro.2016.12.156.

Arenas, C., Vilches, L., Cifuentes, H., Leiva, C., Vale, J., \& Fernandez-Pereira, C. (2011). Development of Acoustic Barriers Mainly Composed of Co-combustion Bottom Ash. World of Coal Ash (WOCA) Conference. Denver: University of Kentucky.

Asadi, I., Shafigh, P., \& Mahyuddin, N. (2018). Concrete as a thermal mass material for building applications - A review. Journal of Building Engineering, 81-93. https://doi.org/10.1016/j.jobe.2018.04.021.

Ashish, D. (2018). Feasibility of waste marble powder in concrete as partial substitution of cement and sand amalgam for sustainable growth. Journal of Building Engineering, 236242. https://doi.org/10.1016/j.jobe.2017.11.024.

Aydin, E., \& Arel, H. Ş. (2019). High-volume marble substitution in cement-paste: Towards a better sustainability. Journal of Cleaner Production, 117801 . https://doi.org/10.1016/j.jclepro.2019.117801.

Barbulescu, G., \& Lafargue, R. (2016). Improving social sustainability through comfortable outdoor spaces. Constanta: Transsolar Academy.

Bostanci, S. C. (2019). Utilisation of wood ash for environmentally friendly concrete production. Fifth International Conference on Sustainable Construction Materials and. London: International Committee of the SCMT conferences.

Bostanci, S. C., Limbachiya, M., \& Kew, H. (2018). Use of recycled aggregates for low carbon and cost effective concrete construction. Journal of Cleaner Production, 176196. https://doi.org/10.1016/j.jclepro.2018.04.090.

Brundtland, G. (1987). Report of the World Commission on Environment and Development: Our Common Future. Oslo: United Nations.

Cheah, B. C., \& Ramli, M. (2011). The implementation of wood waste ash as a partial cement replacement material in the production of structural grade concrete and mortar: An 
overview. Resources, Conservation and Recycling, 669-685. https://doi.org/10.1016/j.resconrec.2011.02.002.

Cheah, C. B., \& Ramli, M. (2012). Mechanical strength, durability and drying shrinkage of structural mortar containing HCWA as partial replacement of cement. Construction and Building Materials, 320-329. https://doi.org/10.1016/j.conbuildmat.2011.12.009.

Chowdury, S., Maniar, A., \& Suganya, O. (2015). Strength development in concrete with wood ash blended cement and use of soft computing models to predict strength parameters. Journal of Advanced Research, 907-913. https://doi.org/10.1016/j.jare.2014.08.006.

Chowdury, S., Maniar, A., \& Suganya, O. (2015). Strength development in concrete with wood ash blended cement and use of soft computing models to predict strength parameters. Journal of Advanced Research, 907-913. https://doi.org/10.1016/j.jare.2014.08.006.

Chowdury, S., Mishra, M., \& Suganya, O. (2015). The incorporation of wood waste ash as a partial cement replacement material for making structural grade concrete: An overview. Ain Shams Engineering Journal, 429-437. https://doi.org/10.1016/j.asej.2014.11.005.

Climate Change Secretariat. (2008). Kyoto Protocol Reference Manual on Accounting of Emissions and Assigned Amount. Bonn: United Nations Framework Convention on Climate Change.

da Luz Garcia, M. \& Sousa-Coutinho, J. (2013). Strength and durability of cement with forest waste bottom ash. Construction and Building Materials, 897-910. https://doi.org/10.1016/j.conbuildmat.2012.11.081.

Demirboga, R. (2007). Thermal conductivity and compressive strength of concrete incorporation with mineral admixtures. Building and Environment, 2467-2471. https://doi.org/10.1016/j.buildenv.2006.06.010.

Desarnaulds, V., Costanzo, E., Carvalho, A., \& Arlaud, B. (2005). Sustainability of acoustic materials and acoustic characterization of sustainable materials. Proceedings of the 12th International Congress on Sound and Vibration, (pp. 18). Lisbon.

Ekinci, A., Hanafi, M., \& Aydin, E. (2020). Strength, Stiffness, and Microstructure of Wood-Ash Stabilized Marine Clay. Minerals. https://doi.org/10.3390/min10090796.

Elinwa, A., \& Mahmood, Y. (2002). Ash from timber waste as cement replacement material. Cement Concrete Composites, 219-222. https://doi.org/10.1016/S0958-9465(01)00039-7.

Federal Highway Administration. (2016). Strategies for Improving Sustainability of Concrete Pavements. Washington: US Department of Transportation.

Hajek, P. (2017). Concrete Structures for Sustainability in a Changing World. Procedia Engineering, 207-214. https://doi.org/10.1016/j.proeng.2017.01.328.

Hammond, G., \& Jones, C. (2011). Inventory of Carbon and Energy Version 2.0. Bath: University of Bath.

Huising, D., Zhang, Z., Moore, J. C., Qiao, Q., \& Li, Q. (2015). Recent advances in carbon emissions reduction: policies, technologies, monitoring, assessment and modeling. Journal of Cleaner Production, 1-12. https://doi.org/10.1016/j.jclepro.2015.04.098.

Ince, C. (2019). Reusing gold-mine tailings in cement mortars: Mechanical properties and socio-economic developments for the Lefke-Xeros area of Cyprus. Journal of Cleaner Production, 117871.
International Maritime Organization. (2014). Third IMO Greenhouse Gas Study 2014. Suffolk: International Maritime Organization.

Jeon, C., Amekudzi, A., \& Guensler, R. (2013). Sustainability assessment at the transportation planning level: Performance measures and indexes. Transport Policy, 10-21. https://doi.org/10.1016/j.tranpol.2012.10.004.

Kalra, M., \& Mehmood, G. (2018). A Review paper on the Effect of different types of coarse aggregate on Concrete. IOP Conference Series: Materials Science and Engineering (pp. 1-7). Bristol: IOP Publishing.

Kazmi, S., Munir, M., Wu, Y.-F., Hanif, A., \& Patnaikuni, I. (2018). Thermal performance evaluation of eco-friendly bricks incorporating waste glass sludge. Journal of Cleaner Production,

$1867-1880$ https://doi.org/10.1016/j.jclepro.2017.11.255.

Khaliq, W., \& Kodur, V. (2011). Thermal and mechanical properties of fiber reinforced high performance selfconsolidating concrete at elevated temperatures. Cement and Concrete Research, 1112-1122. https://doi.org/10.1016/j.cemconres.2011.06.012.

Kizinevic, O., \& Kizinevic, V. (2016). Utilisation of wood ash from biomass for the production of ceramic products. Construction and Building Materials, 264-273. https://doi.org/10.1016/j.conbuildmat.2016.09.124.

Leo Samuel, D., Dharmasastha, K., Shiva Nagendra, S., \& Prakash Maiya, M. (2017). Thermal comfort in traditional buildings composed of local and modern construction materials. International Journal of Sustainable Built Environment, https://doi.org/10.1016/j.ijsbe.2017.08.001.

Meddah, M. S. (2017). Recycled aggregates in concrete production: engineering properties and environmental impact. MATEC Web Conferences Sriwijaya International Conference on Engineering, Science and Technology (p. 05021). Paris: EDP Sciences.

Mishra, G. (2020). Elements or Components of Green BuildingMaterial, Water, Energy Health. Retrieved June 29, 2020, from The Constructor - Civil Engineering Home for Civil Engineers: https://theconstructor.org/building/elements-ofgreen-building/5375/

Naik, T. R., Kraus, R. N., \& Siddique, R. (2002). Demonstration of Manufacturing Technology for Concrete and CLSM Utilizing Wood Ash from Wisconsin. Milwaukee: The University of Wisconsin.

Naik, T. R., Kraus, R. N., \& Siddique, R. (2003). Controlled LowStrength Materials Containing Mixtures of Coal Ash and New Pozzolanic Material. ACI Materials Journal, 208-215.

Ngohpok, C., Satiennam, T., Klungboonkrong, P., \& Chindaprasirt, P. (2018). Mechanical Properties, Thermal Conductivity, and Sound Absorption of Pervious Concrete Containing Recycled Concrete and Bottom Ash Aggregates. KSCE Journal of Civil Engineering, 1369-1376. https://doi.org/10.1007/s12205-017-0144-6

Onuaguluchi, O., \& Eren, Ö. (2016). Reusing copper tailings in concrete: corrosion performance and socioeconomic implications for the Lefke-Xeros area of Cyprus. Journal of Cleaner Production, 420-429. https://doi.org/10.1016/j.jclepro.2015.09.036.

Pavlikova, M., Zemanova, L., Pokorny, J., Zaleska, M., Jankovsky, O., Lojka, M., . . . Pavlik, Z. (2018). Valorization of wood chips ash as an eco-friendly mineral admixture in https://doi.org/10.1016/j.jclepro.2019.117871. 
mortar mix design. Waste Management, 89-100. https://doi.org/10.1016/j.wasman.2018.09.004.

Pedreño-Rojas, M., Morales-Conde, M., Pérez-Gálvez, F., \& Rodríguez-Liñán, C. (2017). Eco-efficient acoustic and thermal conditioning using false ceiling plates made from plaster and wood waste. Journal of Cleaner Production, 690705. https://doi.org/10.1016/j.jclepro.2017.08.077.

Plati, C. (2019). Sustainability factors in pavement materials, design, and preservation strategies: A literature review. Construction and Building Materials, 539-555. https://doi.org/10.1016/j.conbuildmat.2019.03.242.

Prabagar, S., Subasinghe, K., \& Fonseka, K. W. (2015). Wood Ash as an Effective Raw Material For Concrete Blocks. International Journal of Research in Engineering and Technology, 228-233.

Ramos, T., Matos, A., \& Sousa-Coutinho, J. (2013). Mortar with wood waste ash: Mechanical strength carbonation resistance and ASR expansion. Construction and Building Materials, 343-351. https://doi.org/10.1016/j.conbuildmat.2013.08.026.

Rissanen, J., Giosue, C., Ohenoja, K., Kinnunen, P., Marcellini, M., Ruello, M., Illikainen, M. (2019). The effect of peat and wood fly ash on the porosity of mortar. Construction and Building Materials, 421-430. https://doi.org/10.1016/j.conbuildmat.2019.06.228.

Rossit, G., \& Lawson, M. (2012, September 21). Material LIFE: The Embodied Energy of Building Materials. Toronto.

Ruan, S., \& Unluer, C. (2017). Influence of supplementary cementitious materials on the performance and environmental impacts of reactive magnesia cement concrete. Journal of Cleaner Production, 62-73. https://doi.org/10.1016/j.jclepro.2017.05.044.

Sanal, I. (2018). Discussion on the effectiveness of cement replacement for carbon dioxide $(\mathrm{CO} 2)$ emission reduction in concrete. Greenhouse Gases: Science and Technology, 366378. https://doi.org/10.1002/ghg.1748.

Sanal, I. (2018). Significance of Concrete Production in Terms of Carbondioxide Emissions- Social and Environmental Impacts. Journal of Polytechnic, 369-378. DOI: 10.2339/politeknik.389590

Santos, B., Limbourg, S., \& Carreira, J. (2015). The impact of transport policies on railroad intermodal freight competitiveness - The case of Belgium. Transportation Research Part D: Transport and Environment, 230-244. https://doi.org/10.1016/j.trd.2014.10.015.

Scrivener, K. L., John, M. V., \& Gartner, E. M. (2018). Ecoefficient cements: Potential economically viable solutions for a low-CO2 cemet-based materials industry. Cement and Concrete Research. https://doi.org/10.1016/j.cemconres.2018.03.015.

Shi, C., Qu, B., \& Provis, J. (2019). Recent progress in lowcarbon binders. Cement and Concrete Research, 227-250. https://doi.org/10.1016/j.cemconres.2019.05.009.

Shiau, T.-A., \& Liu, J.-S. (2013). Developing an indicator system for local governments to evaluate transport sustainability strategies. Ecological Indicators, 361-371. https://doi.org/10.1016/j.ecolind.2013.06.001.

Siddique, R. (2012). Utilization of wood ash in concrete manufacturing. Resources, Conservation and Recycling, 2733. https://doi.org/10.1016/j.resconrec.2012.07.004.

The Cyprus Institute. (n.d.). Climate Change and Impact. Retrieved June 28, 2020, from The Cyprus Institute: https://www.cyi.ac.cy/index.php/eewrc/eewrc-researchprojects/climate-change-and-impact.html
Timperley, J. (2018, September 13). Why cement emissions matter for climate change. Retrieved June 29, 2020, from Carbon Brief $=>$ Clear on Climate: https://www.carbonbrief.org/qawhy-cement-emissions-matter-for-climate-change

Turkish Standards Institution. (2009). TS 706 EN 12620+A1 Aggregates for Concrete. . Ankara: Turkish Standards Institution.

Turkish Standards Institution. (2012). TS EN 197-1 - Cement Part 1: Composition, Specification and Conformity Criteria for Common Cements. Ankara: Turkish Standards Institution.

Udoeyo, F., Inyang, H., Young, D., \& Oparadu, E. (2006). Potential of Wood Waste Ash as an Additive in Concrete. Journal of Materials in Civil Engineering, 605-611. DOI:10.1061/(ASCE)0899-1561(2006)18:4(605).

United Nations. (2015, December 12). Paris Agreement. Paris, France: United Nations. Retrieved June 28, 2020

Venkataraman, M., Mishra, R., \& Militky, J. (2017). Comparative analysis of high performance thermal insulation materials. Journal of Textile Engineering \& Fashion Technology, 401409. DOI: 10.15406/jteft.2017.02.00062.

World Green Building Council. (2020). Rating tools - World Green Building. Retrieved June 29, 2020, from Home - World Green Building: https:/www.worldgbc.org/rating-tools

World Health Organization (1999) Guidelines for Community Noise. Geneva. World Health Organization, https://www.who.int/docstore/peh/noise/Comnoise-1.pdf.

Yilmaz, M., Tokyay, M., \& Yaman, I. O. (2016). Cement Production by Cement-bonded Wood Particleboard Wastes. Advances in Cement Research, 233-240. https://doi.org/10.1680/jadcr.15.00023.

Zito, P., \& Salvo, G. (2011). Toward an urban transport sustainability index: an European comparison. European Transport Research Review, 179-195. https://doi.org/10.1007/s12544-011-0059-0. 